УДК 130.2

DOI https://doi.org/10.32837/apfs.v0i32.1023

\author{
Ю. Д. Доброносова \\ ORCID ID: https://orcid.org/ 0000-0001-5891-8226 \\ кандидат філософських наук, \\ доиент кафедри філософії та педагогіки \\ Національного транспортного університету
}

\title{
ПРОЄКТИВНИЙ ПОТЕНЦІАЛ РНYGITAL-ПРИСУТНОСТІ В КОНТЕКСТІ ТРАНСФОРМАЦІЙ АКТУАЛЬНОГО МЕДІАДОСВІДУ
}

Постановка проблеми. Еволюція форм медіамережевої комунікації та персонального медіадосвіду протягом кількох десятиліть визначає практики повсякдення і тенденції розвитку культури. Сьогодні цифрові технології впливають на конституювання актуальних життєсвітів, а віртуалізація свідомості індивідів і їхніх соціальних зв'язків, переплетіння офлайн- і онлайн-взаємодій, трансформації співвідношення приватного і публічного зумовлюють характер антропологічних викликів сьогодення, актуальність осмислення яких спонукає до оновлення філософського дискурсу. 3 одного боку, у мережевій культурі ми стикаємося з явищами і процесами, породженими діджиталізацією більшості сфер життєдіяльності особи і суспільства, з іншого - медіакомунікація увиразнює екзистенціальну специфіку людського існування, яка проявляється у феномені присутності. Розгляд специфіки онлайн і офлайн-присутності в горизонті комунікацій цифрової доби дозволяє розкрити витоки нестабільності соціальних структур мережевого соціуму.

Аналіз останніх досліджень i публікацій. Філософські дослідження медіакомунікації належать до актуальних напрямів філософської антропології, філософії медіа, естетики, філософії досвіду. Нерідко пізнання феноменів, породжених поширенням медіатизованої комунікації і соціальних медіамереж, співіснуванням різних поколінь медіа в медіакультурі виводить дослідників на реактуалізацію проблематики екзистенціальної, комунікативної і перцептивної специфіки людського у світі, причому давні сюжети філософських розмислів постають за принципом «вивернутої кишені», коли їх важко розпізнати 3 першого погляду. Таким спрямуванням позначені присвячені пізнанню феномену медіа і медіальності праці Дітмара Кампера [8], Вілема Флюссера [16], Лева Мановича [19], Лідії Стародубцевої [11], Катерини Батаєвої [1], Іллі Інішева [6; 7], Дмитра Петренка [13], Дмитра Куликова [9]. У Бориса Гройса [3], Костянтина Очеретяного [12], Свгенія Уханова [14; 15], Олександра Ленкевича [10] проблематика присутності в медіамережах увиразнюється в аналізі мережевої ідентичності і цифрової чуттєвості. Важливі спостереження щодо специ- фіки медіамережевої присутності містить осмислення кібервоєн Ніка Даєр-Візефорда і Світлани Матвієнко [5]. Попри значну кількість публікацій, автори яких згадують про особливості присутності суб'єкта під час медіакомунікації, або телеприсутності, феномен одночасної присутності медіакомунікантів в онлайн- і офлайн-реальності та переплетіння офлайн- і онлайн-взаємодій у медіадосвіді суб'єкта не досить досліджені.

Метою нашого розгляду є виявлення проєктивного екзистенціального потенціалу Phygital-присутності як нового етапу розвитку індивідуального медіадосвіду. Ї̈̈ реалізація передбачає виконання двох завдань: характеристики амбівалентності Phygital-присутності в горизонті поширення форм офлайн/онлайн-взаємодії і відповідного їм медіадосвіду та з'ясування передумов проявлення іiї проєктивного екзистенціального потенціалу.

Виклад основного матеріалу. Актуальній культурі медіарозмаїття притаманна інтенсивна динаміка розвитку медіамереж і цифрових технологій. Запропоноване нами означення Phygital-nрисутноcті (від англ. Physics - фізичне + англ. Digital-uифрове) фіксує переплетіння двох вимірів існування людини - фізичного офлайн-світу та медіатизованого онлайн-світу. Термін Phygital нині уживають тоді, коли йдеться про доповнену реальність, інтерактивність у комп'ютерних іграх, візії майбутньої інтеграції віртуальної реальності в повсякдення, його вживають фахівці з маркетингу, PR, масових комунікацій, реклами, технологій доповненої реальності. Актуальні обговорення рекламних інновацій рідко минають без згадок про Phygital-маркетинг, Phygital-інструменти i Phygital-технології. У широкому розумінні Phygital - синтез фізичної і цифрової реальності, у вузькому - використання сильних сторін цифрового і нецифрового досвіду особи та перенесення онлайн-звичок в офлайн-повсякдення. Цей термін об'єднує технологічні інновації зі сфери комп'ютерних ігор і розваг, мистецькі й освітні проєкти, використання QR-кодів та інтерактивних бігбордів, доповнену реальність, технології Six Sence, іграшки Toys-to-life. 3 початку другого десятиліття XXI століття Phygital-комунікації зі сфери маркетингу, реклами, експериментального медіамистецтва поширилися на 
актуальне повсякдення. Одним із чинників їх інтенсифікації в персональному медіадосвіді виступає розвиток інтернету речей (англ. internet of things, IoT). В умовах пандемії COVID-19 зросли темпи поширення медіакомунікаційних технологій з опорою на онлайн-офлайн-взаємодії, а співмірний їм медіадосвід став буденним, що й відкрило нові перспективи Phygital-присутності. Співвідношення Physics i Digital у професійній діяльності, освіті, міжособистісній комунікації, розвагах і творчості може бути різноманітним - з акцентуванням на якомусь із вимірів, переважанням одного 3 них, вмонтованістю логіки одного у другий. В ідеалі мало б ітися про гармонізацію Physics i Digital y Phygital-присутності, проте здебільшого маємо справу з гібридизацією або з гойдалкою-коливанням. Початки медіатизованої присутності варто шукати не в медіамережевих технологіях XXI століття, бо й старшим (нецифровим і неелектронним) поколінням медіа притаманна культивація різних форматів присутності. Візуальна, аудіальна i тактильна присутність завжди були передумовою досвіду в межах певного медіа. Будь-який медіадосвід передбачає специфічну форму присутності, aлe y Phygital-присутності йдеться про занурення суб'єкта в розподілене між двома вимірами, але єдине, середовище, у якому особа отримує статус суб'єкта-вузла, завдяки чому й існує така єдність. Так, по-новому актуалізуються питання про стосунки в системі «людина - медіапристрій»: хто і ким управляє, хто насправді є користувачем, хто і для кого виступає медіа? Дослідник мережевого суспільства Ян ван Дейк [20] зазначає, що актуальні соціальні медіамережі, залучені до активної взаємодії з мережами фізичними (екосистеми) і технічними, відчувають впливи органічних мереж / нейронних систем, хоча інфраструктурою мережевого соціуму є мережі соціальні, технологічні та медіамережі. Звичка бути присутніми водночас у цифровій і позацифровій реальностях - базова для актуального повсякдення, а 3 неможливістю реалізувати необхідні Phygital-взаємодії пов'язані і прояви цифрової нерівності. Дизайн взаємодій «переливається» за межі цифрової реальності і перетворюється на інструмент форматування взаємодій у реальності фізичній. Це відбувається завдяки проникненню медіамережевої логіки присутності, дії і комунікації в позамережевий досвід індивіда. Недарма Лев Манович [19] звертає увагу на те, що в актуальній постмедіаестетиці йдеться не про візуальне або аудіальне, а про інтерфейсне, у якому організація стосунків між медіапристроями і медіакомунікантом задає стиль і особливості відчуттів, тобто «софт» управляє суб'єктом. Інтерфейсна природа цифрового у Phygital-взаємодіях містить передумови спрощення людської присутності у світі і спрощеного розуміння управління людським. Костянтин Очеретяний [12, с. 172-173] називає панів- ний сьогодні дизайн інтерфейсів біхевіоральним завдяки йому комп'ютери постають як технології впливу й управління емоціями. Зацикленість цифрових медіа на біхевіоральному породжує загрозу того, що дії людей у Digital-вимірі інтерфейсів медіапристроїв рано чи пізно засвідчать неможливість існувати повноцінно. За потужним потоком повідомлень ми часто відчуваємо обмаль смислів, надмір комунікації обертається на її нестачу, потік інформації супроводжується спрагою розуміння. Образною ілюстрацією до обмеження людського в біхевіоральному дизайні $є$ спрощення функціональності дотику в технологіях сенсорних екранів, коли тактильна здатність втрачає більшість екзистенціальних потенцій. Поширення тільки такого типу дизайну інтерфейсів веде до встановлення спрощеної біхевіоральної логіки Phygital-присутності. Костянтин Очеретяний убачає вихід у доповненні біхеовіорального дизайну екзистенціальним дизайном, заснованим на благоговінні перед життям у його повноті і недосконалості - поверненні користувачів до себе самих, адже Digital-pеальність може виводити нас з фізичного світу, але «за правильного використання може i зіштовхнути людину вперше із собою» [12, с. 187].

Phygital-взаємодії зазвичай амбівалентні, бо містять дві можливості: закріпити панування біхевіоральної логіки стосунків індивідів 3 Іншими, світом і самими собою й уможливити розвиток проєктивного потенціалу медіадосвіду. Присутність особи в цифровій медіареальності структурована алгоритмами, які конституюють їі перцептивний досвід, увагу, тілесність, причому алгоритмізована чуттєвість базується не на дистанції, а на залученості, яку визначають серії операцій, що увиразнюється і в мобілізаційній силі нових медіа. Загроза приватності суб'єкта в мережевому соціумі виростає 3 «фатального перетину між суб'єктом даних і фізичним тілом» [5, с. 32]. Децентралізація і непрозорість мережевої взаємодії впливають на індивіда: суб'єкт залучений до соціальних медіамереж із моменту входу до них, вони пропонують йому численні функції, скорочують відстані і час на виконання повсякденних дій. Профілі дозволяють індивідам по-справжньому стати суб'єктали в медіалережах - бути присутніми певним тілесним, феноменальним i перцептивним способом. Без профілю суб'єкта просто не існує, бо профіль засвідчує його присутність як вузла-в-мережі. Євгеній Уханов зазначає, що в мережевих структурах важливою складовою частиною самовизначення індивіда $€$ взаємодія віртуалізованої соціальної реальності і його внутрішнього світу, коли головна умова - перебувати у стані «між» віртуальним і реальним $[14$, с. 6$]$. Сучасні медіаплатформи дають особі нові можливості або звужують поле їі можливостей. Співіснування і взаємопроникнення повсякдення 
фізичної соціальної реальності та цифрової мережевої реальності зумовлюють часткову віртуалізацію життя індивідів і спільнот, інтенсифікацію чого можна спостерігати від початку пандемії COVID-19. Ігровий і ситуативний характер мережевої ідентичності може сприяти гнучкому соціальному конструюванню медіамережевої комунікації, однак його основою часто виявляється гібридизація цифрової реальності, фізичної реальності і внутрішнього світу індивіда, який залишається частиною Digital-простору навіть тоді, коли безпосередньо в ньому не перебуває, - як «датафікований суб”єкт» [18, с. 35] або ідентичність, створювана на підставі активності індивіда в цифрових мережах, що передбачає збирання воєдино цифрових ідентифікаторів, які збігаються із соціальними кодами й індикаторами, накладаючись, додаючись або й витісняючи їх.

Спостереження за розвитком Phygital-взаємодій як основи Phygital-присутності можуть наштовхнути на думку про те, що гібридність Phygital спроможна вивільнити як потенціальність і надмірність, так і недосконалість комунікативно вкоріненого людського. Лідія Стародубцева [11] називає найбільш відповідним сучасному соціуму означення прозорого суспільства Джанні Ваттімо або суспільства необмежених можливостей і максимальної відкритості особи, адже мережевий соціум спрямований на випрозорювання приватності в медіамережевій комунікації. Вона припускає, що цифрові технології можуть бути як інструментами творення нового порядку, так і гальмом - не лише випрозорювати суспільство, але й заважати цьому, бо феномени телеприсутності й інтернет-присутності творять ілюзію тотальної прозорості. Звісно, щодо чистої Digital-присутності ілюзійний аспект випрозорювання, на який вказує Л. Стародубцева, справді може спрацьовувати, але тоді, коли йдеться про Phygital-присутність, потенціал випрозорювання зростає. Зв'язок випрозорювання приватності в медіамережевому досвіді «датафікованого суб'єкта» (у вимірі Digital) та випрозорювання приватності реального суб'єкта (у вимірі Physics) сьогодні часто є передумовою мережевої комунікації, способом доступу до можливості реальних дій в актуальному повсякденні аж до того, що Phygital-не-присутність в актуальних соціальних взаємодіях може означати ледь не Physics-не-присутність. Розвиток цифрових медіамереж визначає інтенсифікація розвитку хмарних технологій, які поєднуються із предметами в повсякденні і свідомістю індивідів, причому хмарність $є$ інтеграцією різнорідних технічних і програмних елементів і комунікативних засобів, гетерогенних елементів у гомогенні структури. За словами Євгенія Уханова [15], особливістю нових медіатехнологій є репрезентаційне взаємопроникнення, у результаті чого всі репрезентації індивіда в мережевих комунікаціях об'єднуються в єдину хмару репрезентацї̈ й ідентифікації - хмарну ідентичність. Базою для хмарної ідентифікації $\mathrm{e}$ цифрові технології мобільності. Віртуальна хмарність пронизує життєвий простір, мережеві комунікації в розвитку рухаються в напрямку «від суто віртуального, до гомогенізації віртуального і реального" [15, с. 136]. Хмарна ідентифікація є способом засвідчити свою Phygital-присутність, коли гібридизація онлайн- і офлайн-існування відкриває особі можливості перепривласнити відчужене попередніми поколіннями медіа тіло, причому взаємодія з інтерфейсами є способом пізнання власної чуттєвості. Мультимедійність цифрових медіа передбачає розвиток у напрямі залучення можливостей полісенсорного проєктування існування, розподіленого між Physics i Digital. Phygital-взаємодіï конституюють середовище, що структурує простір досвіду, причому характер зв'язків між окремими вузлами медіамереж зумовлює можливості прояву конвергенції тілесного, чуттєвого і смислового, унаслідок чого увиразнюється подієвий і перфомативний характер Phygital-присутності, яка актуалізує співвідношення чуттєвого/смислового. Ïї інтерфейсна основа передбачає визначення кордонів, у яких можливе злиття в єдине середовище онлайну й офлайну. Джей Девід Болтер і Ричард Грузін [17] вказують на два імпульси, притаманні західноєвропейській культурі із часів появи ідеї перспективи: гіпермедіації (прагнення збільшення кількості медіа) і амедіальності (прагнення мати немедіатизований досвід). Актуальне медіарозмаїття пов'язане з накопиченням медіа різних поколінь у полімедіальному досвіді, що виростає з медіальної природи людського існування, де медіальність виступає як переплетіння внутрішнього і зовнішнього в досвіді та долання протиставлення суб'єкта/об'єкта. Якщо виходити з розуміння медіарозмаїття як складного середовища, де внутрішня медіальна структура людської присутності співмірна зовнішній медіальності, то прагнення амедіальної присутності ілюзорне. Внутрішне медіа людської уяви, медіамовлення, медіальна природа свідомості є прикметами людського способу існування. У Phygital-взаємодії ми маємо справу з подвійним рухом, у якому відображається процес зміни поколінь медіа в культурі. У широкому розумінні весь людський досвід є медіадосвідом, а будь-яка присутність - медіаприсутністю з різними ступенями медіації. Digital виступає проєкцією внутрішньої медіальності, яка у Phygital-присутності повертається до своїх витоків, хоча це повернення нагадує рух стрічкою Мебіуса.

Проєктивний потенціал Phygital-присутності пов'язаний із тим, що в мережевому соціумі, за спостереженням Дмитра Куликова [9], медіакомуніканти творять проєктосфери, у яких виступають як проєкти «для себе» і проєкти «для Іншого, 
причому в медіамережах логіка віртуальних взаємодій може бути відмінною від логіки взаємодій в офлайн-реальності. Актуальне медіарозмаїття є мережею, вузлами якої виступають суб'єкти і технічні пристрої, а коди людського і технічного переплітаються. У Phygital-присутності увиразнюється те, що в медіадосвіді завжди маємо справу з комунікацією суб'єкта із самим собою, для якої, проте, потрібен Інший - запорука проєктування як у вимірі Digital, так і у вимірі Physics. Ефективність медіамережевої комунікації часто залежить від долання розриву між Я-реальним і Я-віртуальним та відкриття Іншості. Проєктивний потенціал Phygital-присутності виростає із численних ефектів медіамереж, одним із найважливіших серед яких є респонзитивність Phygital-взаємодій. Запропоноване Бернгардом Вальденфельсом [2] поняття респонзитивності (від лат. responsio відповідати) прояснює деякі аспекти зв'язку між Digital i Physics. На відміну від інтенціональної, респонзитивна раціональність виводить на перший план відгук суб'єкта на виклики дечого чужого йому - як переплетіння викликів і відповідей, де засадовою є неможливість ухилитися від останніх, аж до перетворення не-відповіді у варіант відповіді. Амбівалентність виклику Іншого зумовлює увиразнення екзистенціально-подієвого аспектів відповіді. Представлене Б. Вальденфельсом смислотворення через респонзитивність передбачає творення смислу у відповіді на виклики Чужого, коли важливою є і сама подія відгуку. У мережевій активності відповіді на виклики Інших здатні увиразнити приховані прикмети хмарної ідентичності суб'єкта, вивести його зі схованки, зробити присутнім/вразливим. У Phygital-присутності переплітаються інтенціональна та респонзитивна раціональність, тому мережевий дискурс часто є провокативнил - у ньому постає спокуса виклику, на який має бути відгук, що і засвідчуватиме присутність Я.

Запропонована Вілемом Флюссером [16, с. 72] для характеристики медіакультурного розвитку людства ідея покрокового відступання від життєвого світу передбачала, що з першим кроком із людей, які торкаються речей, ми перетворюємося на обробників, із другим - на спостерігачів, із третім - на скрипторів, а із четвертим - на калькуляторів. Відкинувши доцільність п'ятого кроку в тому самому напрямі, він вказував на потенціал проєктування, яке передбачає зміну суб'єктивної позиції і трансформацію розуміння дистанції і дистантності. Phygital-взаємодії і розподілена Phygital-присутність - подвійно відкрита можливість п'ятого кроку, що може як актуалізувати потенціал проєктування в поверненні до власної тілесності, тілесності Інших і тілесності світу, так і продовжити рух-дистанціювання, який буде радше серіями кроків на місці. Інтенсифікація
Digital-присутності виявляється тим, без чого ми так не могли б інтерекзистенціально відкрити для себе Physics-існування, позначене переплетінням внутрішньої і зовнішньої медіальності. Якщо згадати ідею антропологічного чотирикутника, яка народилася в Дітмара Кампера [8] в діалозі з візією проєктування Вілема Флюссера, то згаданий момент підсилюється. Розподіленість Phygital-чуттєвості передбачає медіадосвід, який потенційно може відсилати до всіх виділених Д. Кампером вимірів, починаючи із часу/крапки, письма/лінії й образу/тіла і завершуючи тілом/простором, причому останній увиразнює статус простору як середовища-лережі. Як тут не згадати, що багато форм цифрової медіаприсутності мають витоки в розвитку комп'ютерних ігор, де тілесність гравця/користувача пов'язана 3 алгоритмічністю i процедурністю, а сам він «занурений у середовище інтерфейсів, вживається в нього, для кращої координації із системою, грою, подієвістю» [10, с. 22]. Характерною прикметою медіаприсутності під час використання Іаджетів є поєднання інтерфейсів і тіл та перфомативність тілесності і свідомості. Часто Phygital у повсякденні потребує від суб'єктів навичок гравців - ідеться про взаємодії медіакористувачів і медіакомунікантів з інтерфейсами мобільних додатків, соціальних мереж, платформ відео- або аудіокомунікації. Олександр Ленкевич [10, с. 30-31] позитивно оцінює потенціал медіадосвіду, який формується в межах комп'ютерних ігор, адже новітні технології занурення, присутності і залучення до потоку цифрового сприйняття конституюють цифрову форму суб'єкта, спроєктованого медіа, і особливу форму його тілесної присутності - так здійснюється перехід від візуально орієнтованої чуттєвості і логіки побудови дистанцій до тактильної перцепції, пов' язаної із зануренням у середовище, водночас через онлайн-досвід відбувається і повернення відчуженого тіла спочатку в перфомативному медіатизованому досвіді, а згодом - у продукуванні присутності.

Згадка продукування присутності невипадкова, адже Phygital-взаємодії конституюють процеси продукування-як-проєктування присутності людського в розподілених середовищах. У концепції продукування присутності Ганс Ульрих Гумбрехт [4] протиставляє ефекти значення й ефекти присутності, пов' язує перші з техніками інтерпретації та забування тіла/ присутності. Продукування присутності вказує на події і процеси, що підсилюють вплив присутніх об'єктів на людські тіла. У У. Гумбрехта присутність протиставлено домінуванню значення, вона передбачає занурення в тілесність світу втіленої людської істоти. Прагнення подолати опозицію суб'єкта й об'єкта в концептуалізації продукування присутності близьке 
до міркувань Моріса Мерло-Понті, сконцентрованих довкола концепту хіазли. Переплетіння тілесності світу і тілесності людини може бути різноманітним, тож хіазма уможливлює середовище присутності. Мотив напруги/конфлікту між значеннями і присутністю У. Гумбрехт окреслює ескізно, а саме з ним ми і стикаємося там, де Digital i Physics стають медіа одне для одного. У Phygital-взаємодії постає прикордоння царства значень і продукування-проєктування присутності, яке увиразнює розмаїття форм тілесності світу, коли навіть вимір Digital отримує право мати власну тілесність. Прикметно, що розмисел щодо хіазматичного переплетіння, обговорення можливості продукування присутності на противагу пануванню значень і окреслення перспектив, які відкриває людському існуванню гібридний Phygital-вимір, ведуть до акцентування на екзистенціальній ролі дотику в майбутніх трансформаціях медіадосвіду і розвитку цифрових технологій, проте цей сюжет потребує окремого дослідження.

Висновки. Осмислення медіадосвіду визначає спрямування сучасного філософського дискурсу на пізнання екзистенціальної потенціальності людського існування в медіакомунікації. Дослідження Phygital-присутності є перспективним напрямом філософії медіа з виразним теоретичним потенціалом. Виведенням на перший план феномен присутності, розподіленої у фізичному і цифровому вимірах ми отримуємо шанси відкрити нову сторінку в пізнанні людського, реактуалізувати феноменологічну методологію, увиразнити ідеї проєктивної здатності людського i продукування-як-проєктування присутності. Проєктивний екзистенціальний потенціал - сутнісна характеристика Phygital-присутності, 3 масштабним поширенням якої пов'язаний новий етап розвитку індивідуального медіадосвіду в актуальній культурі медіарозмаїття. Інтенсивний розвиток медіамереж і цифрових технологій є підставою для поширення в повсякденні Phygital-взаємодій, у яких відбувається занурення суб'єкта-вузла в розподілене між двома вимірами середовище. Інтерфейсна природа Digital-простору породжує амбівалентність Phygital-присутності, у якій може відбуватися спрощення людського, увиразнюватися його потенціальність, надмірність і недосконалість. y Phygital-взаємодіях тіло залучене до різних режимів перцепції, однак на прикордонні фізичного і цифрового дисциплінується тілесність і свідомість.

Перспективними напрямами майбутніх досліджень є осмислення співвідношення зору, дотику і слуху в різних варіантах Phygital-присутності, виявлення її специфіки в контексті розвитку технологій телеприсутності.

\section{Jimepamypa}

1. Батаева Е. Видимое общество. Теория и практика социальной визуалистики. Харьков : ФЛП Лысенко И.Б., 2013. 349 с.

2. Вальденфельс Бернгард. Топографія чужого: студії до феноменології Чужого / пер. з нім. Вахтанга Кебуладзе. Київ : ППС, 2002. 206 с.

3. Гройс Борис. Под подозрением. Феноменология медиа / пер. с нем. Андрея Фоменко. Москва : Художественный журнал, 2006. 200 с.

4. Гумбрехт Ганс Ульрих. Продукування присутності. Що значення не може передати / пер. з англ. Івана Іващенка. Харків : IST Publishing, 2020. 186 с.

5. Даєр-Візефорд Нік, Матвієнко Світлана. Кібервійна і революція / авториз. пер. з англ. Андрія Бондаря. Київ: Критика, 2021. 328 с.

6. Инишев Илья. Интенциональность и медиальность: генезис и трансформация феноменологической герменевтики : автореф. дис. ... докт. филос. наук : 09.00.03. Москва, 2015. 66 с.

7. Инишев Илья. Распределённая образность: имагинативные практики современной культуры. ПРА HМА. 2020. № 1 (23). С. 31-46.

8. Кампер Дитмар. Тела-абстракции. Антропологический четырехугольник: тело, поверхность, линия и точка / пер. с нем. Михаила Степанова. ХОРА. 2010. № $1 / 2(11 / 12)$. С. 47-56.

9. Куликов Д. Феноменологический метод и мир медийных социальных сетей. Ярославский педагогический вестник. 2006. № 1. С. 75-81.

10. Ленкевич Александр. На пути к медиаэстезису: производство присутствия в компьютерных играх. Международный журнал исследований культуры. 2019. № 1. C. $20-33$.

11. Стародубцева Лидия. Паноптикон, «прозрачное общество» и новые медиа. Український соціологічний журнал. 2017. № № 1-2. С. 35-42.

12. Очеретяный Константин. От бихевиорального дизайна к благоговению перед жизнью: политики заботы для цифровой среды. Galactica Media. Jornal of Media Studies. 2021. № 2. C. 166-193.

13. Петренко Д. Воспроизводить и трансверсировать. Философская антропология медиа : монография. Харьков : ХНУ имени В.Н. Каразина, 2016. 372 с.

14. Уханов Є. Мережеві комунікації та соціальне самовизначення індивіда : автореф. дис. ... канд. філос. наук : 09.00.03. Харків, 2010. 16 с.

15. Уханов Е. Облачная идентификация в сетевых коммуникациях. Вісник Харківського національного університету ілені В.Н. Каразина. Серія «Філософія. Філософські перипетії. 2011. № 984. Вип. 44. С. 129-136.

16. Флюссер В. О проецировании / пер. с нем. Михаила Степанова. ХОРА. 2009. № № 3-4. С. 65-76.

17. Bolter J.D., Grusin R. Remediation: Understanding New Media. Cambridge : MIT Press, 1999. 295 p.

18. Cheney-Lippold John. We Are Data: Algorithms and the Making of Our Digital Selves. New York : New York University Press, 2017. 320 p.

19. Manovich L. Post-media Aesthetics. URL: http://manovich.net/index.php/projects/post-mediaaesthetics.

20. Van Dijk J. The Network Society. Social Aspects of New Media. London: Sage Publications, 2006. 336 p. 


\section{Анотація}

Доброносова Ю. Д. Проєктивний потенціал Phygital-присутності в контексті трансформацій актуального медіадосвіду. - Стаття.

Автор виходить із того, що актуальний розвиток філософії медіа передбачає оновлення філософського дискурсу. Дослідження сконцентроване на осмисленні сучасного феномену Phygital-присутності як нового етапу розвитку індивідуального медіадосвіду, виявленні його проєктивного екзистенціального потенціалу. Медіамережеві комунікації свідчать про парадоксальність людського існування. Розвиток цифрових технологій і трансформації персонального медіадосвіду зумовлюють характер сучасних антропологічних викликів. Автор фіксує переплетіння онлайн- і офлайн-вимірів існування людини в означенні Phygital-присутності. Виклики пандемії COVID-19 зумовлюють інтенсифікацію розвитку Phygital-взаємодій. Сьогодні вони визначають актуальне повсякдення, професійну діяльність, освіту, міжособистісну комунікацію, розваги і творчість. У Phygital-присутності суб'єкт занурюється у Phygital-середовище й отримує статус суб'єкта-вузла. Інтерфейсна природа цифрового у Phygital-взаємодіях амбівалентна. Гібридна Phygital-присутність може проявляти надмірність, потенціальність і недосконалість людського існування. Актуальне медіарозмаїття передбачає накопичення різних медіа в полімедіальному персональному досвіді. Медіальність презентує переплетіння внутрішнього і зовнішнього в комунікативному досвіді та долання протиставлення суб'єкта і об'єкта. Автор пропонує розглядати сучасне медіарозмаїття як складне середовище, яке передбачає різні режими перцепції. На кордонах фізичного і цифрового дисциплінується тіло і свідомість. У Phygital-присутності переплітаються інтенціональна і респонзитивна раціональність, Digital i Physics стають медіа одне для одного, а проєктивний екзистенціальний потенціал $€$ ïi сутнісною характеристикою.

Перспективним напрямом подальших досліджень автор уважає розгляд співвідношення зору, дотику і слуху у Phygital-присутності.

Ключові слова: медіа, медіарозмаїття, медіадосвід, Phygital-присутність, проєктивний потенціал.

\section{Summary}

Dobronosova Yu. D. Projective potential of Phygitalpresence in the context of transformation of the actual mediaexperience. - Article.

The author proceeds from the fact that the current development of philosophy involves the renovation of philosophical discourse. The focus of the study is the reflection of modern phenomenon of Phygitalpresence as a new stage in the development of individual mediaexperience and detection its projective existential potential. Media network communication attestes paradoxicality of human existence. The development of digital technologies and the transformation of personal media experience determine the nature of modern anthropological challenges. The author fixes the weaving of online and offline dimensions of human existence in the definition of Phygital-presence. The challeges of COVID-19 pandemic determines the development of intensification of Phygital interactions. Now it defines current everyday life, professional activity, education, inpersonal communication, entertainment and creativity. The subject dives in the Phygital environment and receives the status of the subject-node in the Phygitalpresence. The interface nature of digital in Phygital interactions is ambivalent. The hybrid Phygital-presence can show the redundancy, potentiality and imperfection of human existence. Actual mediadiversity involves the accumulation of different media in multimedia personal experience. Mediality represents the weaving of the internal and external in the communicative experience and overcoming of opposition of subject and object. The author proposes to consider modern media variety as a complex environment with different modes of perception. Body and consciousness are disciplined on the borders of the physical and the digital. Intentional and respositive rationality are weaved in Phygital-presence. Digital and Physics become media for each other, and projective existential potential is its essential characteristic. The author considers as promising direction of future research of study the correlation of sight, touch and hearing in Phygital-presence.

Key words: media, mediavariety, mediaexperience, Phygital-presence, projective potential. 